Click www.researchjournal.co.in/online/subdetail.html to purchase.

INTERNATIONAL JOURNAL OF PLANT PROTECTION

- ISSN-0974-2670 | Visit us : www.researchjournal.co.in

\title{
Influence of bee pollination on quality and quantity of onion (Allium cepa L.) seed
}

\author{
Subhash B. Kandakoor* and Jitendra Kumar S. Hilli ${ }^{1}$ \\ Department of Entomology, University of Agricultural Sciences, Dharwad (Karnataka) India \\ ${ }^{1}$ Seeds Unit, University of Agricultural Sciences, Dharwad (Karnataka) India
}

\section{ARITCLE INFO}

Received : 29.07 .2020

Revised : 12.09 .2020

Accepted : 25.09 .2020

\section{KEY WORDS :}

Honey bees, Pollination, Onion, Inflorescence
*Corresponding author:

Email : subbukandakoor@gmail.com

\begin{abstract}
The activity of bees pollination in onion was observed throughout the day. Numerically maximum activity was observed during afternoon hours (12.00 to $2.00 \mathrm{PM})$ with 7.00 numbers in rock bee, 5.40 in Indian bees, 11.60 in little bees and 7.80 in case of dammer be, respectively. Among the four species of bees, little bees were more in entire day with highest of 111.60 bees/10 inflorescence/ minute followed by dammer bee with 9.40 bees/10 inflorescence/ minute, Among the bees major contributor was little bee, this may be due to more colonies of little bees in that area and destruction of rock bee colonies. Also, the bee acitivty was observed maximum number at 100 per cent flowering stage. The observations on number of seeds per umbel, 1000 seed weight and per cent germination under the laboratory conditions. The results clearly indicated that, maximum number of seeds per umbel was observed in open pollinated flowers with $339.30 \pm 60.27$ seeds per umber where all the four species of bees were made visits regularly followed by in case of pollination in mesh cloth cage with bees with $330.00 \pm 35.80$ and very least number of seed set was observed in case of pollination in mesh cloth cage without bees with only 60.70 seeds/umbel. Similarly, 1000 seed weight also differed significantly in case of pollination with bees and without bees. In case of with bees it weighed around $3.37 \mathrm{~g} / 1000$ seeds followed by $3.10 \mathrm{~g} / 1000$ seeds in onion with bee cage and least in case of control with only $1.97 \mathrm{~g} / 1000$ seeds.
\end{abstract}

How to view point the article : Kandakoor, Subhash B. and Hilli, Jitendra Kumar S. (2020). Influence of bee pollination on quality and quantity of onion (Allium cepa L.) seed. Internat. J. Plant Protec., 13(2) : 200-204, DOI : 10.15740/HAS/IJPP/13.2/200-204, Copyright@ 2020: Hind Agri-Horticultural Society. 